\title{
PELAKSANAAN AKAD BAI BITSAMAN AJIL DALAM TINJAUAN HUKUM ISLAM (STUDI KASUS BMT SIDOGIRI)
}

\author{
Rifqi Nurdiansyah ${ }^{1}$, Muhammad Salman Al Farisi ${ }^{2}$, Achmad Budi Susetyo ${ }^{3}$, \\ Bayu $^{4}$, Sigit Kusbiantoro ${ }^{5}$, Muhajjir ${ }^{6}$ \\ ${ }^{1}$ IAIN Kerinci, ${ }^{2}$ STEBIS Bina Mandiri Cileungsi, ${ }^{3}$ Universitas Nahdlatul Ulama' Blitar, ${ }^{4}$ STIE Umel \\ Tual, ${ }^{5}$ Institut Agama Islam Al-Azhaar Lubuklinggau, ${ }^{6}$ Institut Agama Islam Al-Aziziyah \\ Email: ziyadatulbarkah@gmail,salman@binamandiri.ac.id,achmad.fc@gmail.com, \\ jokka019@gmail.com, sigitkusbiyantoro24@gmail.com, muhajir264@gmail.com
}

\begin{abstract}
ABSTRAK
Pergeseran kebijakan ekonomi nasional yang mengikuti perkembangan ekonomi global telah membuat pemerintah untuk membenahi kegiatan ekonomi negara. Kehadiran lembaga keuangan syariah seperti BMT UGT merupakan pioner untuk membantu masyarakat kalangan menengah kebawah dalam memenuhi kebutuhan simpan pinjam nasabah. Untuk memenuhi kebutuhan nasabah yang beragam BMT UGT Sidogiri melakukan inovasi akad seperti penyertaan akad lain pada suatu akad tertentu. Metode yang digunakan dalam penelitian ini adalah kualitatif meliputi observasi, interview dan library research. Hasil penelitian menunjukkan bahwa aplikasi akad bai bitsaman ajil (BBA) di BMT UGT Sidogiri mensyaratkan harus disertakan akad lain yakni akad wakalah. Model pertama barang diserahkan ke BMT oleh nasabah yang menjadi wakil, baru kemudian diserahterimakan kembali oleh BMT kepada nasabah. Hal ini diperbolehkan dalam hukum Islam dimana pihak BMT UGT Sidogiri dan nasabah telah melakukan akad sesuai dengan syari'at Islam dan ketentuan perbankan. Model kedua, barang langsung dibawa pulang oleh nasabah dan menjadi hak milik, tanpa terlebih dahulu diserahkan kepada BMT, model seperti ini tidak sah karena mengakibatkan terjadinya ittihadul qaabit wal muqbit yang dilarang oleh hukum Islam.
\end{abstract}

Kata Kunci : Pelaksanaan Bitsaman Ajil, UGT Sidogiri, Hukum Islam.

\begin{abstract}
The shift in national economic policy that follows the development of the global economy has led the government to improve the country's economic activities. The presence of sharia financial institutions such as BMT UGT is a pioneer to help the lower middle class in meeting the needs of saving customers' loans. To meet the needs of customers who vary BMT UGT Sidogiri innovate agreements such as the inclusion of other contracts in a particular contract. The methods used in this study are qualitative including observation, interview, and library research. The results showed that the application of the bai' bitsaman jail (BBA) agreement in BMT UGT Sidogiri requires that another contract must be included, namely the wakalah agreement. The first model of goods handed over to BMT by the customer who became a representative, only then handed back by BMT to nasabah. This is allowed in Islamic law where BMT UGT Sidogiri and Customer have agreed to shari'ah Islam and banking regulations. The second model, goods directly brought home by the customer and the property rights, without first handed over to BMT, model is not valid because it results in the occurrence of ittihadul quality wall muqbit which is prohibited by Islamic law.
\end{abstract}

Keywords : Implementation of Bitsaman Ajil, UGT Sidogiri, Islamic Law. 


\section{PENDAHULUAN}

Pergeseran kebijakan ekonomi nasional yang mengikuti perkembangan ekonomi global telah mendorong pemerintah untuk membenahi kegiatan ekonomi masyarakat. Salah satu kegiatan ekonomi yang dibenahi tersebut adalah kegiatan perbankan, karena perbankan merupakan kegiatan yang penting dalam menunjang kegiatan pembangunan nasional. Dimana sistem ekonomi Islam memiliki pijakan yang sangat tegas jika dibandingkan dengan sistem ekonomi liberal dan sosialis yang saat ini mendominasi sistem perekonomian dunia (Hasbi, 2021).

Intrumen hukum yang dibenahi adalah dengan dikeluarkannya undangundang No. 7 Tahun 1992 tentang Perbankan. Dalam Undang-undang ini mulai diakomodasi perbankan Islam dengan nama perbankan bagi hasil, yang kemudian direspon oleh umat Islam yang diwakili oleh Majelis Ulama Indonesia dan organisasi kemasyarakatan dengan membentuk Bank Muamalat Indonesia (BMI). Bank inilah yang merupakan bank umum Islam pertama yang menerapkan prinsip-prinsip keuangan syari'ah yang berbeda dengan sistem perbankan yang selama dikenal oleh masyarakat Indonesia. Hadirnya BMI merupakan jawaban tersendiri bagi umat Islam yang menginginkan transaksi yang bebas riba yang ada di bank konvensional.

Kehadiran lembaga-lembaga keuangan syariah seperti baitul maal wa tamwil (BMT) UGT (Usaha Gabungan Terpadu) Sidogiri direspon dengan antusias oleh umat Islam yang merupakan penduduk mayoritas di Indonesia, hal tersebut ditandai dengan meningkatnya aset yang dimiliki oleh baitul maal wat tamwil (BMT) UGT Sidogiri dari tahun ketahun. Dan ternyata nasabahnya bukan hanya kalangan masyarakat muslim saja akan tetapi juga kalangan non muslim, terutama pengusaha pengusaha keturunan Cina. Hal ini disebabkan baitul maal wat tamwil (BMT) UGT Sidogiri menekankan kewajiban untuk mengungkapkan informasi demi melindungi yang lemah (Aini, 2015).

Sudah cukup lama umat Islam Indonesia dan belahan dunia lainnya menginginkan perekonomian yang berbasis pada nilai-nilai dan prinsip syariah untuk dapat diterapkan dalam segala aspek kehidupan dalam transaksi antar umat yang didasarkan pada aturan syariah. Keinginan ini didasari oleh kesadaran untuk menerapkan Islam secara utuh dalam segala aspek kehidupan. Sebagaimana yang dijelaskan dalam surah Al-Baqarah ayat 208:

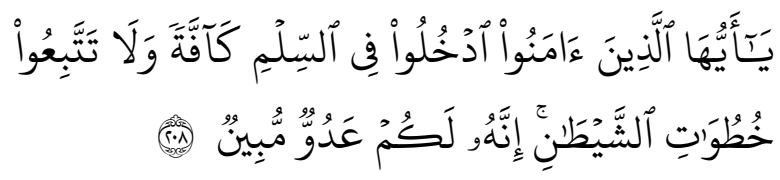

Artinya : "Hai orang-orang yang beriman, masuklah kamu kedalam Islam secara kaffah atau menyeluruh". (Q.S. Al-Baqarah ayat 208)

Ayat ini dengan tegas mengingatkan kepada umat Islam untuk melaksanakan Islam secara kaffah bukan secara parsial, Islam tidak hanya diwujudkan dalam bentuk ritualisme ibadah semata, dan dimarginalkan dari dunia politik, ekonomi, perbankan, asuransi, pasar modal, pembiayaan proyek, transaksi ekspor-impor dan lain-lain, apabila hal ini terjadi, maka umat Islam telah menjauhkan Islam dari kehidupannya.

Berdasarkan hasil penelitian yang dilakukan oleh Bank Indonesia, masih terdapat masyarakat yang enggan berhubungan dengan bank sebagai akibat dari diterapkannya sistem bunga yang diyakini sebagai riba yang diharamkan. Oleh karena itu dibutuhkan suatu konsep alternatif sistem perbankan yang dapat menampung tuntutan dan kebutuhan masyarakat, dengan sistem bai bitsaman ajil (BBA), yang dikatakan berfungsi berdasarkan biaya plus dimana harga jual (dengan laba) aset dibayarkan lewat angsuran atau cicilan selama kurun waktu yang panjang. Bukti konkrit yang perlu diambil ibroh (pelajaran) ketika bunga diterapkan oleh perbankan konvensional, sehingga bangsa Indonesia 
mengalami krisis ekonomi dan moneter yang memporak porandakan sendi-sendi kehidupan bangsa, yang pada akhirnya Indonesia sangat terpuruk dalam berbagai sektor kehidupan.

Salah satu sektor yang sangat mencengangkan adalah ketika perbankan konvensional dengan sistem bunganya mengalami kebangkrutan sejak tahun 1997, tidak kurang sekitar 30 bank ditutup atau dilikuidasi dan selanjutnya ada 55 bank masuk dalam kategori pengawasan oleh Badan Penyehatan Perbankan Nasional (BPPN). Untuk membantu bank-bank tersebut, pemerintah terpaksa membantu dengan mengucurkan bantuan pembiayaan yang dikenal dengan Bantuan Likuiditas Bank Indonesia (BLBI) yang sampai sekarang belum dapat dilunasi oleh pembiayaannya (Nurhayani, 2006).

Kondisi ini sangat berbeda dengan perbankan yang beroperasi sesuai dengan prinsip syariah. Pihak lembaga keuangan syariah bisa mendapatkan dengan cara membeli dan memiliki aset kemudian menjual aset kepada nasabah dimana tingkat keuntungan yang diperoleh lembaga keuangan syariah harus sesuai dengan kesepakatan sejak awal. Dengan sistem tersebut, maka jelas lembaga-lembaga keuangan syariah selamat dari praktek riba. Dengan adanya krisis moneter menjadi langkah awal lembaga keuangan syariah untuk menunjukan eksistensinya, kalau lembaga-lembaga keuangan syariah mampu bertahan dalam keadaan krisis Indonesia sebagai negara berkembang masuk kedalam urutan ke-9 negara sebagai penduduk miskin.

\footnotetext{
Peranan perbankan yang sangat strategis dalam mencapai tujuan pembangunan ekonomi Indonesia dewasa ini memerlukan pengkajian yang seksama atas konsep perbankan yang selama ini dioperasionalkan, baik secara konseptual maupun dalam aplikasinya, sehingga tercipta suatu sistem perbankan yang tangguh di era globalisasi pada masa yang akan datang. Keberadaan lembaga keuangan syariah di Indonesia belum sepenuhnya diterima, masih
}

ada sebagian masyarakat yang menyamakan dengan bank konvensional. Akad bai bitsaman ajil (BBA), pada dasarnya merupakan pembiayaan dengan prinsip tolong menolong dan kesepakatan murni antara kedua belah pihak atau lebih yaitu pemilik modal (investor) dalam hal ini BMT UGT Sidogiri dengan debitur. Dimana kebutuhan ekonomi merupakan kebutuhan masyakat tidak boleh tidak harus dipenuhi oleh semua manusia baik muslim atau pun nonmuslim, karena pada dasarnya seseorang tidak mungkin bisa untuk menjalani hidup dalam keadaan sengsara dengan kemiskinan (Hasbi, 2021).

Secara umum, prinsip pembiayaan syariah dalam lembaga keuangan syariah meletakan 3 hal yaitu, pembiayaan tidak berurusan dengan riba (bunga), tidak bertujuan mendanai aset atau kegiatan haram (dilarang), dan pembiayaan syariah menekankan kewajiban untuk mengungkapkan informasi demi melindungi yang lemah. Secara teoritis prinsip pembiayaan bai bitsaman ajil (BBA) lebih banyak diminati dari kegiatan pembiayaan perbankan syariah. Akan tetapi dalam kegiatan pembiayaan, mudharabah kurang diminati dalam kegiatan pembiayaan.

Pembiayaan mudharabah sangat tinggi (high risk) dan pengembaliannya tidak pasti, padahal perbankan syariah merupakan lembaga bisnis. Dalam lembaga intermediasi bank berfungsi sebagai perantara perbankan syariah yang kekurangan modal (lack of fund) dan pihak lain yang kelebihan modal (surplus of fund), di samping itu perbankan syariah juga harus mengembalikan dana nasabah penabung setiap saat (Hasbi, 2009).

Pada prinsipnya perbankan syariah dengan nasabah harus memahami betul tentang filosofi pembiayaan dengan sistem mudharabah, karena Islam memberikan solusi yang adil bagi kedua belah pihak dengan prinsip pertanggung jawaban yang jelas, bukan hanya ingin mendapatkan keuntungan sendiri sementara pihak yang lain mengalami kerugian bahkan sampai pada titik dimana tidak punya apa-apa 
bahkan secara ekonomi tidak berdaya lagi. Disinilah pentingnya kita mengkaji dan menemukan konsep yang sebenarnya dari prinsip akad bai bitsaman ajil (BBA) dalam lembaga keuangan syari'ah, agar akad bai bitsaman ajil (BBA) menjadi produk pembiayaan yang utama bagi lembagalembaga keuangan syariah pada masa yang akan datang (Mustofa et al, 2020).

\section{TINJAUAN PUSTAKA}

\section{Bai`Bitsaman Ajil (BBA)}

Pengertian al-bai bitsaman ajil (BBA) secara tata bahasa dapat diartikan sebagai pembelian barang dengan pembayaran cicilan atau angsuran. Prinsip bai bitsaman ajil (BBA) merupakan pengembangan dari prinsip murabahah. Jadi dalam hal ini pihak perbankan membiayai pembelian barang yang diperlukan nasabah dengan sistem pembayaran angsuran. Dalam pelaksanaannya dengan cara pihak baitul mal wat tamwil (BMT) membeli atau memberi surat kuasa kepada nasabah untuk membelikan barang yang diperlukannya atas nama BMT (Hasbi, 2009).

Selanjutnya pada saat yang sama baitul mal wa tamwil (BMT) menjual barang tersebut kepada nasabah dengan harga sebesar harga pokok ditambah sejumlah keuntungan atau mark-up, di mana jangka waktu serta besarnya angsuran berdasarkan kesepakatan bersama antara baitul mal wa tamwil (BMT) dengan nasabah.

\section{Transaksi Bai Bitsaman Ajil (BBA) di Perbankan Syariah}

Bai atau jual-beli adalah akad yang dihalalkan dan disyariatkan Islam. Baik dengan harga tunai atau dengan kredit. Diantaranya mensyaratkan manfaat pada salah seorang diantara yang melakukan transaksi. Misal, saya jual rumah ini dengan syarat saya tinggal dahulu satu tahun. Transaksi jenis diperselisihkan ulama. Madzhab Malik dan Hambali membolehkannya, sedangkan madzhab Syafi'i melarangnya (Iswanaji et al, 2021).
Istilah bai bitsaman ajil (BBA) sesungguhnya istilah yang baru dalam literatur fiqih Islam. Meskipun prinsipnya memang sudah ada sejak masa lalu. Secara makna harfiyah, bai maknanya adalah jualbeli atau transaksi. Tsaman maknanya harga dan ajil maknanya bertempoh atau tidak tunai. Jenis transaksi ini sesuai dengan namanya adalah jual-beli yang uangnya diberikan kemudian atau ditangguhkan. tsaman ajil maknanya adalah harga belakangan. Maksudnya harga barang itu berbeda dengan bila dilakukan dengan tunai (Hasbi, 2020).

Contohnya, sebuah mobil bila dibeli dengan tunai, harganya 100 juta. Tetapi karena pelunasannya memerlukan waktu 5 tahun (ajil), maka harganya menjadi 130 juta. Setelah itu nasabah melakukan pembayaran cicilan bulanan berjumlah tetap pada bank selama 5 tahun itu. Dengan asumsi cicilan Rp. 500.000,- maka selama 5 tahun jumlah total Rp. 30.000.000,- akan terbayarkan.

\section{Landasan Hukum}

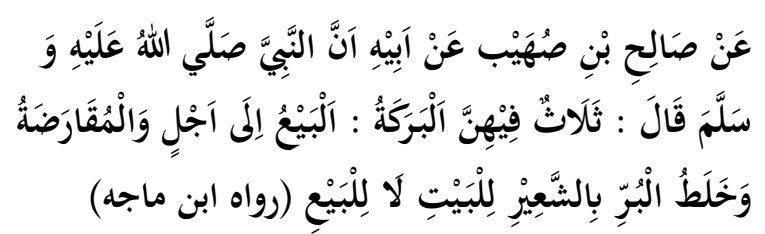

Artinya: "Dari shalih bin Suhaib Ar Rumi $r$,a., bahwa Rasulullah SAW bersabda, "tiga hal yang di dalamnya terdapat keberkatan: jual-beli secara tangguh, muqaradhah (mudharabah), dan mencampur gandum dengan tepung untuk keperluan rumah, bukan untuk dijual." (H.R. Ibnu Majah).

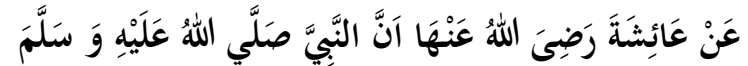

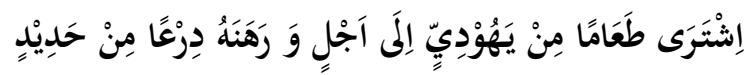

$$
\begin{aligned}
& \text { (رواه البخاري) }
\end{aligned}
$$

Artinya: "Dari Aisyah r.a. bahwa Rasulullah membeli makanan dari seorang yahudi dan menjaminkan kepadanya baju besi." (H.R. Bukhari Nomor 1926). 
Dalam hadis Riwayat Bukhari dijelaskan bahwa Rasulullah SAW pernah membeli makanan secara berutang (sekarang dikenal dengan transaksi bai bitsaman ajil), dari Aisyah r.a. bahwa Rasulullah SAW membeli makanan dari Zafar secara tangguh dan baju besinya sebagai jaminan. Kontrak ba'i bitsaman ajil (BBA) tidak dibahas secara khusus dalam kitab klasik, seperti jual-beli bertangguh yang lain (Al-salam), namun transaksi ini benar-benar dilakukan oleh nabi, yang mana pada gilirannya nanti menjadi embrio dari transaksi jual-beli berbasis hutang yang kita kenal sekarang ini dengan bai bitsaman ajil (BBA).

Adapun terdapat beberapa penelitian terdahulu yang relevan dengan penelitian ini antara lain : Pertama, penelitian yang dilakukan oleh Kurniawan (2012), bertujuan untuk mengetahui produk pembiayaan bai bitsaman ajil apakah sesuai dengan ketentuan syariah dan bagaimana pengaruhnya terhadap perkembangan usaha mikro di daerah pasar. Hasil penelitian ini menunjukkan bahwa penerapan pembiayaan bai bitsaman ajil di BMT Ikhlasul Amal berjalan lancar dalam peningkatan kemampuan ekonomi nasabah. Hal ini ditunjukan melalui uji statistik diperoleh koefisien korelasi $\mathrm{r}=0,072$. Setelah dikonfirmasikan dengan rho tabel dengan $\mathrm{N}$ $=20$ dengan tingkat signifikasi $5 \%$ rho tabel 0,423 . Artinya terdapat hubungan yang positif antara penerapan pembiayaan bai bitsaman ajil dengan peningkatan kemampuan ekonomi nasabah pasar Karangampel di BMT Ikhlasul Amal.

Kedua, penelitian yang dilakukan Fitria dan Qulub (2019), untuk mengetahui bagaimana peran baitul maal wat tamwil (BMT) Pinar Bersinar Utama Surabaya terhadap pemberdayaan ekonomi pedagang kecil di Pasar Pucang Surabaya. Metode penelitian yang digunakan adalah pendekatan studi kasus kualitatif. Hasil penelitian ini adalah baitul maal wat tamwil telah berperan dalam meningkatkan usaha pedagang kecil di Pasar Pucang Surabaya. Peningkatan bisnis dari pedagang kecil dapat dilihat dari anggota baitul mal wat tamwil (BMT) yang berdagang di Pasar Pucang mengalami peningkatan pendapatan dan kelancaran bisnis dari waktu ke waktu. Hasil penelitian ini juga diperkuat oleh penelitian Prasetya dan Herianingrum (2016), bahwa pada umunya BMT memiliki peran penting untuk meningkatkan usaha mikro dari pelanggan.

\section{METODE PENELITIAN}

Penelitian ini mendasarkan pada penelitian hukum yang dilakukan dengan pendekatan doktrinal atau normatif yang memandang hukum sebagai seperangkat aturan atau kaidah yang bersifat normatif, dan pendekatan non doktrinal atau pendekatan sosiologis. Hal ini disebabkan karena di dalam penelitian, hukum tidak hanya diartikan atau dikonsepkan sebagai keseluruhan asas atau kaidah yang mengatur kehidupan manusia dalam masyarakat, melainkan meliputi pula lembaga-lembaga dan proses yang mewujudkan berlakunya hukum.

Pendekatan yang digunakan dalam penelitian ini adalah pendekatan yuridis empiris, yaitu yang memandang hukum bukan saja sebagai seperangkat kaidah yang bersifat normatif atau apa yang menjadi teks Undang-Undang (law in books), akan tetapi juga melihat bagaimana hukum berinteraksi dengan masyarakat (law in action). Sehubungan dengan permasalahan yang diangkat adalah implementasi akad bai bitsaman ajil (BBA) di BMT UGT Sidogiri, maka diharapkan akan diperoleh pemahaman yang integral dari aspek hukum baik hukum Islam maupun hukum nasional (Arliman, 2018).

Selanjutnya penelitian ini menggunakan metode kualitatif yang diharapkan dapat ditemukan makna-makna yang tersembunyi di balik permasalahan sebagai objek yang akan diteliti.

\section{HASIL DAN PEMBAHASAN}

Salah satu produk pembiayaan di BMT UGT Sidogiri adalah akad bai bitsaman ajil 
(BBA). Al-bai bitsaman ajil (BBA) dapat diartikan sebagai pembelian barang dengan pembayaran cicilan atau angsuran. Prinsip bai bitsaman ajil (BBA) merupakan pengembangan dari prinsip murabahah. Jadi dalam hal ini pihak perbankan membiayai pembelian barang yang diperlukan nasabah dengan sistem pembayaran angsuran. Dalam pelaksanaannya, ketika nasabah mengajukan pembiayaan, akad ini diterapkan dengan cara pihak baitul maal wat tamwil (BMT) membeli sendiri atau BMT UGT Sidogiri mengangkat nasabah sebagai agen (yang diberi kuasa) melakukan pembelian barang atas nama pihak baitul maal wat tamwil (BMT). Dengan demikian pihak BMT mewakilkan pembelian barang kepada nasabah yang mengajukan pembiayaan, dengan demikian nasabah tidak berposisi sebagai nasabah yang mengajukan pembiayaan namun memposisikan diri sebagai wakil dari Baitul Maal Wat Tamwil (BMT) (Puspita \& Farida, 2015).

Wakalah yang dilakukan oleh BMT UGT Sidogiri harus disertakan dalam akad bai bitsaman ajil (BBA), dimana baitul maal wat tamwil (BMT) dalam penyediaan barang berkerjasama dengan dealer, pengepul dan sebagainya. Oleh karena itu BMT UGT Sidogiri untuk menyediakan barang dengan sendiri mengalami sedikit kendala dimana ruangan sempit tidak dan tidak dapat menampung. Selanjutnya praktek yang dilakukan di BMT UGT Sidogiri disinyalir termasuk praktek transaksi barang yang dilarang, yakni taadudus shafaqah yaitu transaksi barang dengan akad ganda.

Berikut dibawah ini skema dalam proses transaksi yang dilakukan oleh BMT UGT Sidogiri.

Tabel 1. Prosedur Pengajuan Pembiayaan BMT UGT Sidogiri

\section{TATACARA ATAU PROSEDUR}

\section{PENGAJUAN DAN PROSES PEMBIAYAAN}

\begin{tabular}{|c|c|c|}
\hline PENGAJUAN/PERMOHONAN & PROSES & REALISASI \\
\hline $\begin{array}{l}\text { 1. Mengisi formulir pengajuan pembiayaan. } \\
\text { 2. Penyerahkan persyaratan pengajuan } \\
\text { pembiayaan: } \\
\text { a. Copy KTP/SIM suami-istri } \\
\text { b. Copy KSK } \\
\text { c. Copy surat akta nikah } \\
\text { d. Copy surat jaminan beserta aslinya } \\
\text { e. Surat penyataan dari pemilik jaminan } \\
\text { untuk jaminan yang bukan atas nama } \\
\text { pemohon }\end{array}$ & $\begin{array}{ll}\text { 1. } & \begin{array}{l}\text { Menerima dan } \\
\text { memeriksa }\end{array} \\
\text { pengajuan } & \\
\text { pembiayaan. } & \\
\text { 2. } & \begin{array}{l}\text { Survey dan } \\
\text { wawancara kepada }\end{array} \\
\text { pemohon. } & \\
\text { 3. } & \text { Analisa pembiayaan }\end{array}$ & 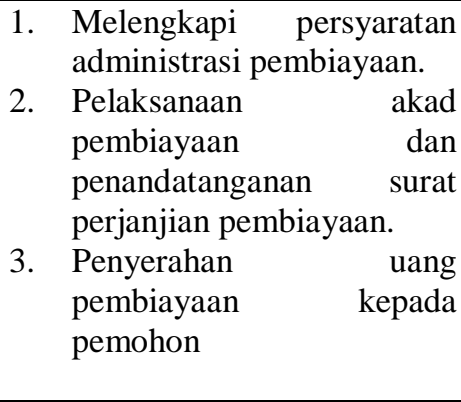 \\
\hline
\end{tabular}

\section{Sumber : Data BMT Sidogiri (2020)}

Dalam proses pengajuan di BMT UGT Sidogiri tidak ada biaya sama sekali. Kemudian ketentuan yang menjadi pertimbangan diterimanya pengajuan yakni nasabah bisa dikatakan orang yang berkarakter baik, punya usaha yang sekiranya dia mampu untuk melunasi.

Tashawwur taaddudus shafaqah (akad ganda) di literatur fiqh klasik semisal kitab i anatut thalibin dicontohkan seperti seorang syarikain (dua orang bermitra) menjual satu barang kepada seorang pembeli, yang mana barang tersebut dimiliki oleh dua orang.
Kemudian jika dibandingkan dengan proses akad bai' bithsaman ajil di BMT UGT Sidogiri, ada dua macam yaitu: Pertama, seorang nasabah mengajukan pembelian suatu barang melalui baitul maal wat tamwil (BMT) dengan cara jual beli murabahah, dimana nasabah akan membayar secara kredit kepada baitul maal wat tamwil (BMT) yang membelikan barang itu secara kontan. Namun, dalam hal ini BMT tidak membeli barang itu secara langsung, melainkan BMT mewakilkannya pada nasabah. Dengan demikian nasabah berposisi sebagai wakil dari baitul maal wat tamwil 
(BMT) dalam pembelian barang tersebut sehingga terjadi akad wakalah dan belum terjadi akad hutang yang mengakibatkan akad yang dilakukan tidak sah.

Solusinya adalah nasabah yang statusnya menjadi wakil seharusnya menyerahkan terlebih dahulu barang tersebut kepada baitul maal wat tamwil (BMT) atau melakukan sesuatu yang mengindikasikan adanya serah terima antara nasabah yang berstatus wakil tadi dengan pihak baitul maal wat tamwil (BMT) yang berposisi sebagai muwakkil. Kemudian baitul maal wat tamwil (BMT) menyerahkan kepada nasabah kembali. Saat itulah terjadi serah terima barang sebagai akad hutang.

Perbedaan antara margin dengan bunga adalah bahwa margin itu ditentukan berdasarkan kesepakatan antara pihak nasabah dengan baitul maal wat tamwil (BMT) dengan memandang harga pasaran barang yang dibeli. Selain itu, margin tidak bertambah atau berkembang akibat keterlambatan pembayaran dari tempo yang ditentukan. Artinya baitul maal wat tamwil (BMT) tidak mewajibkan denda apapun pada nasabah yang tidak mampu, melainkan hanya melakukan klarifikasi alasan keterlambatan nasabah dalam pembayaran hutang sesuai dengan tempo yang telah disepakati untuk mengambil sebuah kebijakan. Berbeda halnya dengan bunga yang bisa membengkak setiap kali terlambat dari tempoh pembayaran. Dimana bunga ditentukan secara sepihak dari pihak bank berdasarkan naik turunnya inflasi.

Dalam kajian hukum Islam wakil (nasabah) harus menyerahkan terlebih dahulu barang kepada baitul maal wat tamwil (BMT) dimana nasabah hanya sebagai seorang wakil bukan peminjam resmi. Setelah itu dilakukan proses akad hutang/ bai' bithsaman ajil (BBA) dari pihak baitul maal wat tamwil (BMT) dengan nasabah. Dengan demikian BBA tidak mengandung taaddudus shafaqah (akad ganda), karena pada awalnya nasabah yang hendak membeli barang melalui baitul maal wat tamwil (BMT) diposisikan sebagai wakil dari baitul maal wat tamwil (BMT) dalam pembelian barang tersebut. Setelah proses akad wakalah selesai barulah ia menjadi nasabah dengan akad bai' bithsaman ajil (BBA) (Putra, 2015).

Proses kedua, barang langsung dibawa pulang oleh nasabah dan menjadi hak milik, dalam hal ini perlu ada tinjauan ulang. Karena mengingat status nasabah masih menjadi seorang wakil dari baitul maal wat tamwil (BMT) yang menurut hukum Islam belum berhak memiliki barang itu. Seharusnya wakil menyerahkan barang terlebih dahulu kepada muwakkil (pihak baitul maal wat tamwil), baru kemudian baitul maal wat tamwil (BMT) menyerahan kembali kepada nasabah yang menjadi wakil dengan status sebagai pemberi pinjaman dan saat itulah terjadi serah terima barang sebagai akad hutang. Jika tidak demikian maka akan terjadi 'ittihaadul qaabit wal muqbit', dimana wakil berstatus ganda, sebagai penerima dan orang yang menyerahkan kepada dirinya sendiri. Dalam kajian literatur fiqh klasik praktek 'ittihaadul qaabit wal muqbit' syari 'at dilarang dalam Islam.

\section{KESIMPULAN}

Implementasi akad baitul maal wat tamwil di BMT UGT Sidogiri disyaratkannya adanya akad wakalah, karena pada waktu-waktu tertentu pihak baitul maal wat tamwil (BMT) tidak bisa mendatangkan sendiri barang yang diinginkan nasabah. Ada dua macam bentuk proses yang terjadi. Pertama, barang masih diserahkan ke baitul maal wat tamwil (BMT) oleh nasabah yang menjadi wakil, baru kemudian diserahterimakan kembali oleh baitul maal wat tamwil (BMT) kepada nasabah seperti pembelian kendaraan bermotor.

Kedua, barang langsung dibawa pulang oleh nasabah dan menjadi hak milik, tanpa terlebih dahulu diserahkan kepada baitul maal wat tamwil (BMT) seperti pembelian pupuk kandang, perahu dan yang semisal yang sulit dibawa ke kantor baitul maal wat tamwil (BMT) UGT Sidogiri. 
Pandangan hukum Islam terhadap transaksi akad bai bitsaman ajil adalah sah. Menjadi tidak sah jika mengakibatkan terjadinya ittihaadul qaabit wal muqbit yang dilarang oleh hukum Islam. Solusinya adalah wakil menyerahkan barang terlebih dahulu kepada muwakkil atau melakukan sesuatu yang mengindikasikan adanya serah terima antara nasabah yang berstatus wakil dengan pihak baitul maal wat tamwil selanjutnya muwakkil menyerahkan kembali barang itu kepada nasabah yang berstatus wakil dan terjadi serah terima barang sebagai akad bai bitsaman ajil (BBA).

\section{DAFTAR PUSTAKA}

Aini, Aisyah Nur. 2015. Pengaruh Tingkat Margin Terhadap Keputusan Pengambilan Pembiayaan Murabahah Di BMT Ugt Sidogiri Cabang Waru Sidoarjo. El-Qist, 05(01), p. 943-962.

Arliman S, Laurensius. 2018. Peranan Metodologi Penelitian Hukum di Dalam Perkembangan Ilmu Hukum di Indonesia. Soumatera Law Review, 1(1), p. 112-132.

Fitria, Evi Nur., \& Qulub, A. Syifa'ul. 2019. Peran BMT dalam Pemberdayaan Ekonomi (Studi Kasus pada BMT Padi Bersinar Utama Surabaya). Jurnal Ekonomi Syariah Teori dan Terapan, 6(11), p. 2303-2330.

Hasbi, M. Zidny Nafi'. 2009. Dampak Krisis Keuangan Global terhadap Perbankan di Indonesia: Perbandingan antara Bank Konvensional dan Bank Syariah. La_Riba, 3(1), p. 12-23.

Hasbi, M. Zidny Nafi'. 2021. Usaha Pondok Pesantren Riyadlul Jannah Pacet Mojokerto Dalam Mengembangkan Perekonomian Pesantren Perspektif Ilmu Ekonomi Syariah. Lisan Al-hal, 15(1), p. 85-96.

Iswanaji, Chaidir., Hasbi, M. Zidny Nafi' ., \& Amin, Mohammad. 2021. Implementasi Analitycal Networking Process (ANP) Distribusi Zakat Terhadap Pembangunan Ekonomi
Masyarakat Berkelanjutan (Study Kasus Lembaga Baznas Kabupaten Jember Jawa Timur). Jurnal Tabarru': Islamic Banking and Finance, 4(1), p. 195-208.

Kurniawan, Arif. 2012. Pembiayaan Bai' Bitsaman Ajil Dan Pengaruhnya Terhadap Perkembangan Usaha Mikro Kecil Menengah (UMKM). Skripsi Fakultas Syariah. IAIN Syekh Nurjati Cirebon.

Nurhayani. 2006. Upaya Penyelesaian BLBI (Bantuan Likuiditas Bank Indonesia). Lex Jurnalica, 4(01), p. 28-38.

Prasetya, R. A. and Herianingrum, S. 2016. Peranan Baitul Maal Wa Tamwil Meningkatkan Usaha Mikro Melalui Pembiayaan Mudharabah. Jurnal Syarikah: Jurnal Ekonomi Islam, 2(2), p. 252-267.

Puspitasari, Hasanah, N. \& Farida, L. 2015. Risiko Akad Murabahah Serta Pengelolaan Risiko Akad Murabahah pada BMT-UGT Sidogiri cabang Wongsorejo, Kabupaten Banyuwangi. e-journal Ekonomi Bisnis dan Akuntansi, 2(1), p. 1-5.

Putra, Purnama. 2015. Kinerja Baitul Maal Wa At-Tamwil (BMT) Maslahah Lil Ummah-Pondok Pesantren Sidogiri Menggunkan Balance Scorecard Modifikasian. JRAK: Jurnal Riset Akuntansi \& Komputerisasi Akuntansi, 6(02), p. 45-64.

Mustofa, Arga Fajar., Santi, Mei., \& Sultoni, Hasan. 2020. Analisis Pelaksanaan Akad Bai' Bitsaman Ajil Dan Penetapan Margin Keuntungan Pada Pembiayaan Modal Kerja Usaha Mikro Di Baitul Maal Wa Tamwil Muamalah Tulungagung. Journal of Islamic Banking, 1(1), p. 1-32. 